\title{
Assessment the Physico-Chemical Characteristics of Water and Sediment in Rosetta Branch, Egypt
}

\author{
Yasser Ahmed El-Amier, Mahmoud Abd El-Kawy Zahran, Sadam Hameed Al-Mamory \\ Faculty of Science, Department of Botany, Mansoura University, Mansoura, Egypt \\ Email: yasran@mans.edu.eg
}

Received 3 August 2015; accepted 15 September 2015; published 21 September 2015

Copyright (C) 2015 by authors and Scientific Research Publishing Inc.

This work is licensed under the Creative Commons Attribution International License (CC BY).

http://creativecommons.org/licenses/by/4.0/

(c) (i) Open Access

\begin{abstract}
Water quality of Rosetta Branch may be changed by several factors in the last decades as a result of anthropogenic activities. So, it's important to study the physicochemical characteristics of both water and sediment in the Rosetta Branch. Two identified sources are the main origin of most pollutants in this branch, namely: El-Rahawy drain and industrial activities in Kafr El-Zayat city. From the data of water quality index (WQI) based on six important parameters $\left(\mathrm{pH}, \mathrm{T}^{\circ} \mathrm{C}, \mathrm{DO}, \mathrm{BOD}\right.$, COD and TP), it indicates that site 2 (from Kom Hamada to Edfina) is more polluted than the other two sites (from El-Qanater El-Khairia to Kom Hamada and from Edfina to Rosetta). The concentrations of heavy metals increase in sites that are more affected by drainage water from different drains. Great efforts are needed and wastewater must be treated before draining it into the River Nile water.
\end{abstract}

\section{Keywords}

Rosetta Branch, Physicochemical Characteristics, Pollution, WQI

\section{Introduction}

The River Nile is the major regular and voluminous supply of water secured in Egypt [1] [2]. In a survey of world freshwater, it has been reported that Egypt is one among the top first ten countries to be scare of water by the year 2025 due to the rapidly increasing population [3]. The agricultural activities and domestic wastes are the main sources of water pollutants in the River Nile.

The Rosetta Branch runs for about $220 \mathrm{~km}$ in length with average width $180 \mathrm{~m}$ and with an average depth varies between 1.5 - $16.0 \mathrm{~m}$. It flows downstream Delta Barrage to the NW where it ends with Edfina Barrage which

How to cite this paper: El-Amier, Y.A., El-Kawy Zahran, M.A. and Al-Mamory, S.H. (2015) Assessment the Physico-Chemical Characteristics of Water and Sediment in Rosetta Branch, Egypt. Journal of Water Resource and Protection, 7, $1075-1086$. 
releases excess water to the Mediterranean Sea. Unfortunately, it receives polluted waters from different sources including industrial, agricultural and urban sewage that are causing serious environmental impacts on its freshwater [4]. It is affected by the agricultural drains located along the branch and by the industrial companies at Kafr El-Zayat city. The drains are EL-Rahawy, Sabal, El Tahrir, Zaweit El-Bahr and Tala. These agricultural drains also receive domestic water from 55 towns and villages distributed along this branch. The industrial effluents are from El-Maliya, Mobidat and Salt and Soda companies which are discharging directly at the east bank of the branch. These two sources of pollution potentially affect and deteriorate its quality of water [5].

Pollution can be defined as the change of physical, chemical and biological properties of water, restricting or preventing its use in the various applications [6]. Important physical and chemical parameters influencing the aquatic environment are temperature, rainfall, $\mathrm{pH}$, salinity, dissolved oxygen. Others are total suspended and dissolved solids, total alkalinity and acidity and heavy metal contaminants. These parameters are the limiting factors for the survival of aquatic organisms (flora and fauna). Poor water qualities may be caused by low water flow, municipal effluents and industrial discharges [7].

The cost of the environmental degradation due to water pollution is relatively high with serious health and quality of life consequences; as well as increasing the severity of water scarcity problems. Hence, increasing water pollution causes not only the deterioration of water quality but also threatens human health and the balance of aquatic ecosystems, economic development and social prosperity [8]. The closed water system of Egypt makes it more vulnerable to quality deterioration in a northward direction toward the Nile Delta [9].

The water quality index (WQI) is a mathematical model used to integrate complex data to generate a score that describes the status of water quality to the public as well as decision and policy makers [10] [11]. WQI may also be used for comparing the quality of different water sources and monitoring the temporal changes in water quality [12]. The aim of this study was to analyze the river water quality of Rosetta Branch, Nile Delta, Egypt. Therefore, the physical and chemical parameters of water as well as those of sediment were determined.

\section{Materials and Methods}

\subsection{Study Area}

Rosetta Branch, as shown in Figure 1, located at the western part of the Nile Delta. Its length is about $220 \mathrm{~km}$, average width $180 \mathrm{~m}$ with an average depth varies between 1.5 - $16.0 \mathrm{~m}$. It serves five governorates of the Nile Delta: Qaliubiah, Kafr El-Sheikh, El-Gharbia, El-Menofyia and El-Behira. The study area divided into three sites as follows: site 1 (from El-Qanater El-Khairia to Kom Hamada), site 2 (from Kom Hamada to Edfina) and site 3 (from Edfina to Rosetta).

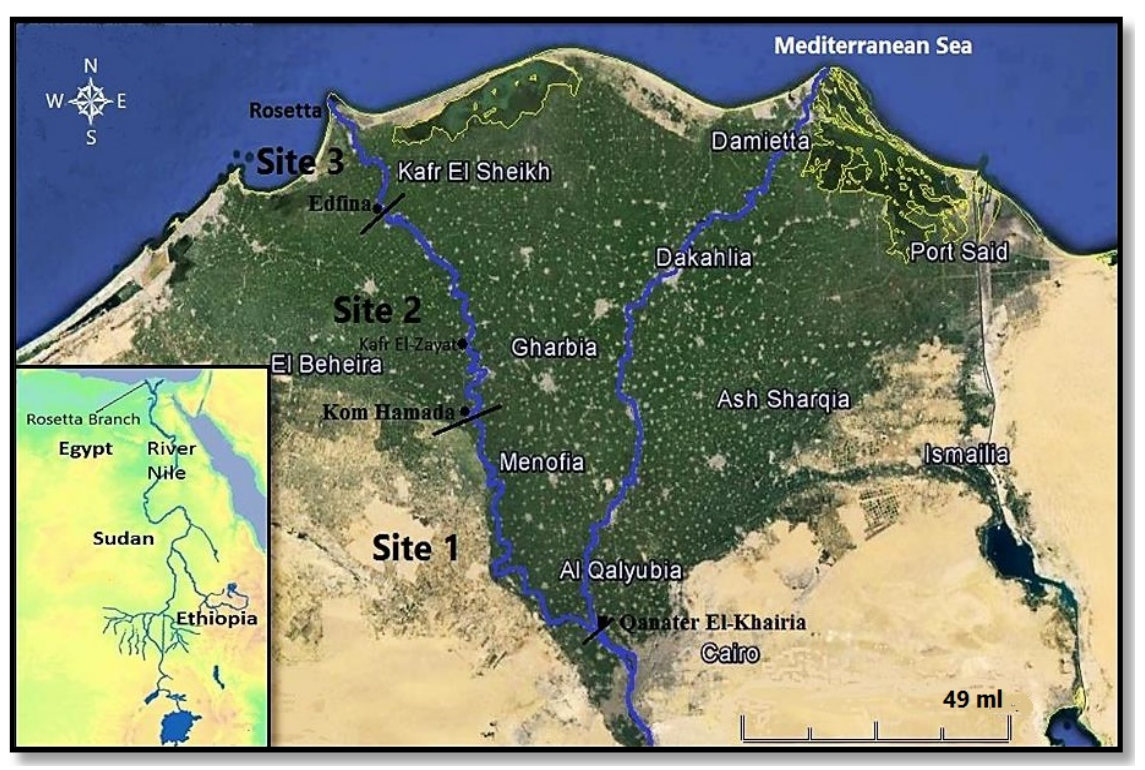

Figure 1. Map of the Nile Delta showing different ecological sites of the study area. 
According to the map of the world distribution of the arid regions [13], the climatic conditions of the Nile Delta are similar to those of the northern part of Egypt, it is rather arid to semiarid, where the rate of evaporation exceeds many times the rate of precipitation. The mean minimum air temperature varies from $6.2^{\circ} \mathrm{C}$ in February to $23.6^{\circ} \mathrm{C}$ in August. The mean maximum air temperature ranges between $17.4^{\circ} \mathrm{C}$ in January to $34.2^{\circ} \mathrm{C}$ in July. The relative humidity ranges from $51 \%$ in May to $76 \%$ in December. The total annual rainfall ranged between 38.1 - $190.8 \mathrm{~mm}$ along the Branch from south at Shebin El-Kome city to the north at Rosetta city. The evaporation attains the highest annual mean value $(6.8 \mathrm{~mm} /$ day $)$ at Tanta and the lowest value $(4.2 \mathrm{~mm} /$ day $)$ at Rosetta.

\subsection{Analytical Methods}

\subsubsection{Sediment Analysis}

Sediment samples were collected from the 50 stands of the ecological sites for soil analysis. The texture of sediment samples, water-holding capacity, oxidizable organic carbon and chlorides was determined according to Piper [14]. Calcium carbonate content was determined according to Jackson [15]. Electric pH-meter was used to determine the soil reaction. Electrical conductivity was measured by YSI Incorporated Model 33 conductivity meter. Carbonates and bicarbonates were determined according to Pierce et al. [16]. Suphates were estimated gravimetrically and the total dissolved phosphorus was determined by direct stannous chloride method [17], while the total nitrogen was determined by the micro-Kjeldahl method according to Allen et al. [18] and heavy metals ( $\mathrm{Fe}, \mathrm{Mn}, \mathrm{Zn}, \mathrm{Pb}, \mathrm{Cu}, \mathrm{Ni}, \mathrm{Cd}$ and $\mathrm{Co}$ ) were carried out according to Allen et al. [19].

\subsubsection{Water Analysis}

Water temperature was measured using YSI model 33 S.C.T. meter, electrical conductivity was measured directly using conductivity meter (Model Corning, NY 14831 USA), The pH value of surface water was measured in situ by using Electrical-pH meter (Model Lutron YK-2001pH meter). Dissolved oxygen was measured directly using dissolved oxygen meter (Lutron YK-22 DO meter). The BOD, COD, chloride and total phosphorus according to APHA [17]. Calcium carbonate content was determined according to Welch (1948). Sulphate content was estimated gravimetrically according to Jackson [15]. Water-soluble carbonates and bicarbonates were determined according to Baruah and Barthakur [20]. The total nitrogen was determined by the micro-Kjeldahl method according to Allen et al. [18] and heavy metals ( $\mathrm{Fe}, \mathrm{Mn}, \mathrm{Zn}, \mathrm{Pb}, \mathrm{Cu}, \mathrm{Ni}$, $\mathrm{Cd}$ and $\mathrm{Co}$ ) were carried out according to Allen et al. [19].

\subsection{Statistical Analysis}

The data of the different ecological sites were compared by one-way ANOVA. The one-way ANOVA and correlation analyses were conducted using SPSS 16 for Windows.

\subsection{Water Quality Index (WQI)}

WQI is 100 points scale that was used to summarize results from different physicochemical measurements using computer program created by the National Sanitation Foundation, USA. The used parameters are: $\mathrm{pH}, \mathrm{T}{ }^{\circ} \mathrm{C}, \mathrm{DO}$, BOD, COD and TP. This index reduces huge amounts of data to a single number thus ranking water into one of five categories: very bad water (0 - 25), bad (25 - 50), medium (50 - 70), good (70 - 90) and excellent quality of the sampled water $(90-100)$. It can be calculated as the following equation:

$$
W Q I=K \frac{\sum_{i} C_{i} W_{i}}{\sum_{i} W_{i}}
$$

where: $K$ is a subjective constant representing the visual impression of river water quality. WQI ranges from 0.25 (highly polluted water) to a maximum value of 1.0 (good quality water). $C_{i}$ is the value assigned to each measured parameter after normalization on a scale from 0 to 100 , where; Zero indicates water that is not suitable for the intended use without further treatment and 100 represents perfect water quality. $\mathrm{W}_{i}$ is the relative weight assigned to each parameter. A maximum weight of 4 was assigned to parameters of relevant importance for aquatic life such as DO, while the minimum value (unity) was assigned to parameters with minor relevance such as temperature and $\mathrm{pH}$.

Full details about the index with a free calculating program are available at the following website http://www.water-research.net/watrqualindex/waterqualityindex.htm. 


\section{Results}

\subsection{Sediment Characteristics}

The physical and chemical characteristics of the sediments collected from three ecological sites of the Rosetta Branch of the River Nile are shown in Table 1. Chloride, bicarbonate, total nitrogen, sodium and SAR showed highest significant correlations $(P<0.05)$ among three ecological sites. Chlorides and $\mathrm{Na}^{+}$showed high mean concentrations ( $1.40 \%$ and $147.86 \mathrm{mg} / 100 \mathrm{~g}$, respectively) in site 3 and bicarbonate $(1.05 \%)$ in site 2 , while the lowest mean value was recorded in site $1(0.21 \%, 50.02 \mathrm{mg} / 100 \mathrm{~g}$ and $0.82 \%$, respectively). Total nitrogen showed high mean concentrations (3.96 mg/100g) in site 1 , while the lowest mean values of TN was observed in site $3(2.36 \mathrm{mg} / 100 \mathrm{~g})$. On the other hand, electrical conductivity, $\mathrm{pH}, \mathrm{K}^{+}$and SAR exhibited low significant correlations $(P<0.05)$ among three ecological sites. The $\mathrm{pH}$ - values ranged between neutral to alkaline along this branch. Electrical conductivity, SAR and $\mathrm{K}^{+}$exhibited the highest mean value $(1833.40 \mu \mathrm{mhos} / \mathrm{cm}, 22.32$ and $41.54 \mathrm{mg} / 100 \mathrm{~g})$ were recorded in site 3, while the lowest mean value of EC and SAR $(494.31 \mu \mathrm{mhos} / \mathrm{cm}$ and 11.94) were recorded in site 2, except $\mathrm{K}(12.13 \mathrm{mg} / 100 \mathrm{~g})$ in site 1.

Table 1. Means and standard errors of sediment characteristics collected from three ecological sites of Rosetta Branch of River Nile. WHC = Water holding capacity, OC = Organic carbon, EC = Electrical conductivity, TP = Total phosphorus, TN $=$ Total nitrogen, $\mathrm{PAR}=$ Potassium adsorption ratio, $\mathrm{SAR}=$ Sodium adsorption ratio, ns $=$ non-significant, *: Values are significant at $\mathrm{P}<0.05, * *$ : values are significant at $\mathrm{P}<0.01$, ***: values are significant at $\mathrm{P}<0.01$. Different superscript letters indicate a significant difference between different sites.

\begin{tabular}{|c|c|c|c|c|c|c|c|}
\hline \multirow{2}{*}{\multicolumn{2}{|c|}{$\begin{array}{l}\text { Sediment } \\
\text { variables }\end{array}$}} & \multicolumn{3}{|c|}{ Ecological sites } & \multirow{2}{*}{$\begin{array}{c}\text { Mean } \\
(n=50)\end{array}$} & \multirow{2}{*}{ F-Value } & \multirow{2}{*}{$\mathbf{L S D}_{0.05}$} \\
\hline & & Site $1(n=20)$ & Site $2(n=20)$ & Site $3(n=10)$ & & & \\
\hline Sand & & $89.64^{\mathrm{ab}} \pm 1.05$ & $85.18^{\mathrm{b}} \pm 0.77$ & $90.87^{\mathrm{a}} \pm 28.74$ & $88.56 \pm 10.19$ & 3.29 & $4.32^{\mathrm{ns}}$ \\
\hline Clay & \multirow[t]{2}{*}{$\alpha^{\circ}$} & $8.56^{\mathrm{a}} \pm 0.97$ & $12.77^{\mathrm{a}} \pm 0.71$ & $7.23^{\mathrm{a}} \pm 2.29$ & $9.52 \pm 1.32$ & 0.44 & $0.72^{\mathrm{ns}}$ \\
\hline Silt & & $1.80^{\mathrm{ab}} \pm 0.15$ & $2.06^{\mathrm{a}} \pm 0.16$ & $1.90^{\mathrm{b}} \pm 0.60$ & $1.92 \pm 0.30$ & 3.79 & $3.90^{*}$ \\
\hline \multicolumn{2}{|l|}{$\mathrm{EC}(\mu \mathrm{mhos} / \mathrm{cm})$} & $522.85^{\mathrm{b}} \pm 66.86$ & $494.31^{b} \pm 58.33$ & $1833.40^{\mathrm{a}} \pm 579.77$ & $950.19 \pm 234.99$ & 5.03 & $1061.50 *$ \\
\hline \multicolumn{2}{|l|}{$\mathrm{pH}$} & $8.23^{\mathrm{a}} \pm 0.09$ & $8.14^{\mathrm{ab}} \pm 0.08$ & $7.84^{b} \pm 2.48$ & $8.07 \pm 0.88$ & 7.68 & $0.30^{* *}$ \\
\hline \multicolumn{2}{|l|}{ WHC } & $48.43^{b} \pm 2.08$ & $57.17^{\mathrm{a}} \pm 3.52$ & $46.59^{b} \pm 14.73$ & $50.73 \pm 6.78$ & 3.66 & $10.45^{*}$ \\
\hline \multicolumn{2}{|l|}{$\mathrm{CaCO}_{3}$} & $4.76^{\mathrm{a}} \pm 0.66$ & $4.55^{\mathrm{a}} \pm 0.57$ & $4.76^{\mathrm{a}} \pm 1.51$ & $4.69 \pm 0.91$ & 0.11 & 2.35 \\
\hline \multicolumn{2}{|l|}{ OC } & $0.99^{\mathrm{a}} \pm 0.13$ & $0.92^{\mathrm{a}} \pm 0.19$ & $1.29^{\mathrm{a}} \pm 0.41$ & $1.06 \pm 0.24$ & 1.45 & $0.62^{\mathrm{ns}}$ \\
\hline $\mathrm{Cl}^{-}$ & ১0 & $0.21^{\mathrm{b}} \pm 0.02$ & $1.33^{\mathrm{a}} \pm 0.04$ & $1.40^{\mathrm{a}} \pm 0.44$ & 0.98 & 56.71 & $0.25^{* * *}$ \\
\hline \multicolumn{2}{|l|}{$\mathrm{SO}_{4}^{-}$} & $1.11^{\mathrm{a}} \pm 0.06$ & $1.06^{\mathrm{a}} \pm 0.02$ & $1.30^{\mathrm{a}} \pm 0.41$ & $1.16 \pm 0.16$ & 1.53 & $0.31^{\mathrm{ns}}$ \\
\hline \multicolumn{2}{|l|}{$\mathrm{HCO}_{3}^{-}$} & $0.82^{\mathrm{c}} \pm 0.01$ & $1.05^{\mathrm{a}} \pm 0.02$ & $0.98^{\mathrm{b}} \pm 0.31$ & $0.95 \pm 0.16$ & 35.98 & $0.06^{* * *}$ \\
\hline \multicolumn{2}{|l|}{$\mathrm{TN}$} & $3.96^{\mathrm{b}} \pm 0.36$ & $3.15^{\mathrm{a}} \pm 0.54$ & $2.36^{\mathrm{C}} \pm 0.75$ & $3.16 \pm 0.55$ & 26.19 & $0.16^{* * *}$ \\
\hline \multicolumn{2}{|l|}{$\mathrm{TP}$} & $0.74^{\mathrm{a}} \pm 0.04$ & $1.00^{\mathrm{a}} \pm 0.04$ & $0.48^{\mathrm{a}} \pm 0.15$ & $0.74 \pm 0.08$ & 1.14 & $1.78^{\mathrm{ns}}$ \\
\hline $\mathrm{Na}^{+}$ & $\vec{\theta}$ & $50.02^{b} \pm 5.72$ & $59.52^{\mathrm{b}} \pm 5.39$ & $147.86^{\mathrm{a}} \pm 46.76$ & $85.8 \pm 19.29$ & 14.65 & $43.80^{* * *}$ \\
\hline $\mathrm{K}^{+}$ & $\stackrel{0}{8}$ & $12.13^{b} \pm 1.72$ & $17.12^{\mathrm{ab}} \pm 3.87$ & $41.54^{\mathrm{a}} \pm 13.14$ & $23.59 \pm 6.24$ & 3.44 & $22.71^{*}$ \\
\hline \multicolumn{2}{|l|}{$\mathrm{Ca}^{++}$} & $24.77^{b} \pm 2.23$ & $28.35^{\mathrm{ab}} \pm 5.47$ & $63.89^{\mathrm{a}} \pm 20.21$ & $39.00 \pm 9.30$ & 3.27 & $34.30^{\mathrm{ns}}$ \\
\hline \multicolumn{2}{|l|}{$\mathrm{Mg}^{++}$} & $16.56^{\mathrm{a}} \pm 2.60$ & $29.38^{\mathrm{a}} \pm 8.23$ & $35.78^{\mathrm{a}} \pm 11.31$ & $27.24 \pm 7.38$ & 1.77 & $26.89^{\mathrm{ns}}$ \\
\hline \multicolumn{2}{|l|}{ SAR } & $13.54^{\mathrm{b}} \pm 1.14$ & $11.94^{\mathrm{b}} \pm 1.67$ & $22.32^{\mathrm{a}} \pm 7.06$ & $15.93 \pm 3.29$ & 8.97 & $6.67^{* *}$ \\
\hline \multicolumn{2}{|l|}{ PAR } & $2.59^{\mathrm{a}} \pm 0.28$ & $3.28^{\mathrm{a}} \pm 0.66$ & $5.80^{\mathrm{a}} \pm 1.83$ & $3.89 \pm 0.92$ & 1.78 & $3.20^{\mathrm{ns}}$ \\
\hline
\end{tabular}




\subsection{Water Characteristics}

The physical and chemical proprieties of water samples from three ecological sites of the Rosetta Branch of the River Nile are shown in Table 2. Water variables showed highest significant correlations $(P<0.05)$ among three ecological sites, except $\mathrm{pH}$ and sulphates. $\mathrm{pH}$ values in water were varied from neutral to slightly alkaline. EC increases from site 1 to site 3 and ranged between 323.63 to $18663.20 \mu \mathrm{mhos} / \mathrm{cm}$. Organic Matter indicators (BOD and COD) exhibited the highest mean value (23.29 and $69.87 \mathrm{mg} / \mathrm{l})$ in site 2, while the lowest mean value was obtained in site 3 (9.78 and $13.20 \mathrm{mg} / \mathrm{l})$.

For anions, the highest mean values were recorded in site 3 except for $\mathrm{SO}_{4}$, in site 2 and their values are (6526.58, 4075.33 and $4142.68 \mathrm{mg} / \mathrm{l}$ ) for $\mathrm{Cl}, \mathrm{SO}_{4}$ and $\mathrm{HCO}_{3}$, respectively. While, the lowest mean value of these was recorded in site 1 (664.58, 2557.80 and $244.18 \mathrm{mg} / \mathrm{l})$ for $\mathrm{Cl}, \mathrm{SO}_{4}$ and $\mathrm{HCO}_{3}$. TN and TP in water samples take the same distribution as their lowest mean values were recorded in site $3(0.72$ and 1.33$)$ and the highest mean values were (3.14 and 2.16) which were recorded in site 2 for TN and TP, respectively. The lowest mean values of cations were recorded in site 1 and their highest mean values were recorded in site 3 as they ranged between (245.46 - 4405.43; 34.28 - 519.94; 32.19 - 1135.50 and 28.42 - 445.72) for Na, K, Ca and Mg, respectively. For the calculated SAR and PAR, the lowest mean values were recorded in site 1 (27.52 and 3.89) and the highest mean values were recorded in site 3 (155.91 and 18.17) for SAR and PAR, respectively.

Table 2. Means and standard errors of water sample characteristics collected from three ecological sites of Rosetta Branch of River Nile. $\mathrm{EC}=$ Electrical conductivity, $\mathrm{DO}=$ Dissolved oxygen, BOD = Biological oxygen demand, COD = Chemical oxygen demand, $\mathrm{TP}=$ Total phosphorus, $\mathrm{TN}=$ Total nitrogen, $\mathrm{PAR}=$ Potassium adsorption ratio, $\mathrm{SAR}=$ Sodium adsorption ratio, WQI: water quality index, $\mathrm{ns}=$ non-significant, *: Values are significant at $\mathrm{P}<0.05$, **: values are significant at $\mathrm{P}<0.01$, ***: values are significant at $\mathrm{P}<0.01$. Different superscript letters indicate a significant difference between different sites.

\begin{tabular}{|c|c|c|c|c|c|c|c|}
\hline \multirow{2}{*}{ Water Variables } & \multicolumn{3}{|c|}{ Ecological sites } & \multirow{2}{*}{$\begin{array}{c}\text { Mean } \\
(n=50)\end{array}$} & \multirow{2}{*}{ F-Value } & \multirow{2}{*}{$\mathbf{L S D}_{0.05}$} & \multirow{2}{*}{$\begin{array}{c}\text { *Egyptian } \\
\text { law No. } \\
\text { 48/1982 }\end{array}$} \\
\hline & Site $1(n=20)$ & Site $2(n=20)$ & Site $3(n=10)$ & & & & \\
\hline Depth (cm) & $5.69^{\mathrm{b}} \pm 184.39$ & $\mathrm{~b} 176.98^{\mathrm{b}} \pm 7.07$ & $218.79^{\mathrm{a}} \pm 12.88$ & $133.82 \pm 68.11$ & 6.18 & $29.49^{* *}$ & - \\
\hline Temp. $\left({ }^{\circ} \mathrm{C}\right)$ & $30.25^{\mathrm{a}} \pm 0.38$ & $30.26^{\mathrm{a}} \pm 0.34$ & $22.86^{\mathrm{a}} \pm 0.32$ & $27.79 \pm 0.35$ & 90.40 & $1.37^{* * *}$ & - \\
\hline $\mathrm{pH}$ & $7.76^{\mathrm{a}} \pm 0.08$ & $7.93^{\mathrm{a}} \pm 0.06$ & $7.96 a \pm 0.03$ & $7.88 \pm 0.06$ & 1.36 & $0.25 \mathrm{~ns}$ & $7-8.5$ \\
\hline $\mathrm{EC}(\mu \mathrm{mhos} / \mathrm{cm})$ & $323.63^{\mathrm{a}} \pm 18.72$ & $626.05^{\mathrm{b}} \pm 17.66$ & $18663.20^{\mathrm{a}} \pm 382.01$ & $938.63 \pm 139.46$ & 2241.93 & $643.38^{* * *}$ & - \\
\hline DO & $10.40^{\mathrm{b}} \pm 0.52$ & $10.82^{\mathrm{b}} \pm 0.34$ & $13.32^{\mathrm{a}} \pm 0.42$ & $11.51 \pm 0.43$ & 5.92 & $1.98^{* *}$ & $\geq 5 \mathrm{mg} / \mathrm{l}$ \\
\hline BOD & $9.78^{\mathrm{b}} \pm 1.48$ & $23.29^{\mathrm{a}} \pm 1.95$ & $12.86^{\mathrm{b}} \pm 1.92$ & $15.31 \pm 1.78$ & 10.03 & $6.89^{* * *}$ & $\leq 6 \mathrm{mg} / \mathrm{l}$ \\
\hline COD & $26.37^{\mathrm{b}} \pm 3.93$ & $69.87^{\mathrm{a}} \pm 6.36$ & $13.20^{\mathrm{b}} \pm 0.70$ & $36.48 \pm 3.66$ & 31.91 & $16.93^{* * *}$ & $\leq 10 \mathrm{mg} / \mathrm{l}$ \\
\hline $\mathrm{Cl}^{-}$ & $664.58^{\mathrm{c}} \pm 151.56$ & $1403.81^{\mathrm{b}} \pm 184.33$ & $6526.58^{\mathrm{a}} \pm 385.88$ & $2864.99 \pm 240.59$ & 111.80 & $870.19^{* * *}$ & - \\
\hline $\mathrm{SO}_{4}^{-}$ & $2557.80^{b} \pm 604.79$ & $4075.33^{\mathrm{a}} \pm 1118.28$ & $3582.24^{\mathrm{ab}} \pm 305.0$ & $3405.12 \pm 676.02$ & 2.72 & $3526.76 n s$ & $\leq 200$ \\
\hline $\mathrm{HCO}_{3}^{-}$ & $244.18^{\mathrm{c}} \pm 19.70$ & $759.95^{\mathrm{b}} \pm 116.01$ & $4142.68^{\mathrm{a}} \pm 275.47$ & $1715.60 \pm 137.06$ & 125.49 & $537.70^{* * *}$ & $<200 \mathrm{mg} / \mathrm{l}$ \\
\hline $\mathrm{CaCO}_{3}$ & $105.44^{b} \pm 3.81$ & $164.99^{\mathrm{a}} \pm 4.60$ & $161.05^{\mathrm{a}} \pm 7.54$ & $143.83 \pm 5.32$ & 37.24 & $16.64^{* * *}$ & 50 - 200 mg/l \\
\hline T.N & $2.68^{\mathrm{b}} \pm 0.10$ & $3.14^{\mathrm{a}} \pm 0.11$ & $0.72^{\mathrm{c}} \pm 0.10$ & $2.18 \pm 0.1$ & 129.01 & $0.35^{* * *}$ & - \\
\hline T.P & $1.46^{\mathrm{b}} \pm 0.05$ & $2.16^{\mathrm{a}} \pm 0.06$ & $1.33^{\mathrm{b}} \pm 0.05$ & $1.65 \pm 0.05$ & 32.87 & $0.24^{* * *}$ & - \\
\hline $\mathrm{Na}^{+}$ & $245.46^{\mathrm{b}} \pm 55.82$ & $491.05^{\mathrm{b}} \pm 72.45$ & $4405.43^{\mathrm{a}} \pm 302.76$ & $1713.98 \pm 143.68$ & 151.11 & $560.16^{* * *}$ & - \\
\hline $\mathrm{K}^{+}$ & $34.28^{\mathrm{b}} \pm 5.02$ & $59.49^{b} \pm 7.53$ & $519.94^{\mathrm{a}} \pm 35.35$ & $204.57 \pm 15.97$ & 159.02 & $63.79^{* * *}$ & - \\
\hline $\mathrm{Ca}^{2+}$ & $32.19^{\mathrm{b}} \pm 8.92$ & $63.50^{\mathrm{b}} \pm 18.94$ & $1135.50^{\mathrm{a}} \pm 78.29$ & $410.40 \pm 35.38$ & 167.57 & $141.17^{* * *}$ & - \\
\hline $\mathrm{Mg}^{2+}$ & $28.42^{\mathrm{b}} \pm 4.43$ & $57.34^{\mathrm{b}} \pm 8.02$ & $445.72^{\mathrm{a}} \pm 41.53$ & $177.16 \pm 17.99$ & 85.68 & $74.0^{* * *}$ & - \\
\hline SAR & $27.52^{\mathrm{b}} \pm 5.15$ & $45.90^{\mathrm{b}} \pm 5.17$ & $155.91^{\mathrm{a}} \pm 4.82$ & $76.44 \pm 5.05$ & 106.16 & $20.35^{* * *}$ & - \\
\hline PAR & $3.89^{b} \pm 0.58$ & $5.46^{\mathrm{b}} \pm 0.61$ & $18.17^{\mathrm{a}} \pm 0.55$ & $9.17 \pm 0.58$ & 102.81 & $2.30^{* * *}$ & - \\
\hline WQI & 59.28 & 44.28 & 60 & - & - & - & - \\
\hline
\end{tabular}

*Egyptian standard regularities of article 60-law No. 48/1982 regarding minimum standards for the water quality of the Nile River. 
Moreover, The WQI values indicated some variations in water quality between the different samples in all ecological sites. With highest quality at site 1 (from El-Qanater El-Khairia to Kom Hamada), while lowest quality at site 2 (from Kom Hamada to Edfina). The water quality during these sites fluctuated from good to bad water (Figure 2).

\subsection{Heavy Metals Concentrations in Sediment and Water Samples}

The cited results in Table 3 show the concentrations of the heavy metals of the sediment and water samples collected from Rosetta Branch of the River Nile (3 sites, 50 stands). Heavy metals (Fe, Mn, Zn, Cu, Pb, Ni, Cd and Co) of the sediment and water variables showed highest significant correlations $(P<0.05)$ among three ecological sites, except $\mathrm{Mn}, \mathrm{Cd}$ and $\mathrm{Co}$ in sediment and $\mathrm{Cu}$ and $\mathrm{Ni}$ in water. It is obvious that the iron ion concentrations in the sediment (28.61, 28.63 and $26.25 \mathrm{mg} / \mathrm{kg}$ ) and water $(0.44,0.33$ and $0.47 \mathrm{mg} / \mathrm{l})$ samples were high compared to the other elements, in site 1,2 and 3, respectively.

Zinc, copper, lead, nickel ions exhibited the highest concentration (5.45, 5.10, 5.47 and $2.79 \mathrm{mg} / \mathrm{kg}$, respectively) in site 2, while, the lowest mean value $(2.90,2.89,3.35$ and $1.68 \mathrm{mg} / \mathrm{kg}$, respectively) were recorded in sediment of site 3 . In water samples, the highest concentration of manganese $(0.27 \mathrm{mg} / \mathrm{l})$, lead $(0.10 \mathrm{mg} / \mathrm{l})$, cadmium $(0.04 \mathrm{mg} / \mathrm{l})$ and cobalt $(0.07 \mathrm{mg} / \mathrm{l})$ recorded in site 3 , while the lowest concentration $(10.0,0.06,0.03$ and $0.03 \mathrm{mg} / \mathrm{l})$ estimated in site 1 and 2.

Table 3. Means and standard errors of heavy metals in sediment and water samples collected from three ecological sites of Rosetta Branch of River Nile. ns $=$ non-significant, *: Values are significant at $\mathrm{P}<0.05,{ }^{* *}$ : values are significant at $\mathrm{P}<0.01$, $* * *$ : values are significant at $\mathrm{P}<0.01$. Different superscript letters indicate a significant difference between different sites.

\begin{tabular}{|c|c|c|c|c|c|c|c|}
\hline \multirow{2}{*}{ Heavy metals } & \multicolumn{3}{|c|}{ Ecological sites } & \multirow{2}{*}{$\begin{array}{c}\text { Mean } \\
(\mathrm{n}=50)\end{array}$} & \multirow{2}{*}{ F-Value } & \multirow{2}{*}{$\mathbf{L S D}_{0.05}$} & \multirow{2}{*}{$\begin{array}{c}{ }^{*} \text { Egyptian } \\
\text { law No. } \\
48 / 1982\end{array}$} \\
\hline & Site $1(n=20)$ & Site $2(n=20)$ & Site $3(n=10)$ & & & & \\
\hline \multicolumn{8}{|c|}{ Sediments (mg/kg) } \\
\hline $\mathrm{Fe}$ & $28.61^{\mathrm{a}} \pm 0.43$ & $28.63^{\mathrm{a}} \pm 0.53$ & $26.25^{\mathrm{b}} \pm 0.50$ & $27.83 \pm 0.49$ & 14.26 & $1.45^{* * *}$ & - \\
\hline Mn & $17.40^{\mathrm{a}} \pm 0.24$ & $16.94^{\mathrm{a}} \pm 0.24$ & $16.99^{\mathrm{a}} \pm 0.33$ & $17.11 \pm 0.27$ & 1.18 & $0.83^{\mathrm{ns}}$ & - \\
\hline $\mathrm{Zn}$ & $4.79^{\mathrm{b}} \pm 0.14$ & $5.45^{\mathrm{a}} \pm 0.14$ & $2.901^{\mathrm{c}} \pm 0.24$ & $4.38 \pm 0.17$ & 52.64 & $0.55^{* * *}$ & - \\
\hline $\mathrm{Cu}$ & $4.31^{\mathrm{b}} \pm 0.15$ & $5.10^{\mathrm{a}} \pm 0.14$ & $2.89^{\mathrm{c}} \pm 0.21$ & $4.1 \pm 0.17$ & 39.46 & $0.55^{* * *}$ & - \\
\hline $\mathrm{Pb}$ & $4.77^{\mathrm{b}} \pm 0.13$ & $5.47^{\mathrm{a}} \pm 0.12$ & $3.35^{\mathrm{c}} \pm 0.26$ & $4.53 \pm 0.17$ & 35.43 & $0.56^{* * *}$ & - \\
\hline $\mathrm{Ni}$ & $2.68^{\mathrm{a}} \pm 0.10$ & $2.79^{\mathrm{a}} \pm 0.08$ & $1.68^{\mathrm{b}} \pm 0.14$ & $2.38 \pm 0.11$ & 22.69 & $0.37^{* * *}$ & - \\
\hline Cd & $0.49^{\mathrm{a}} \pm 0.08$ & $0.40^{\mathrm{a}} \pm 0.05$ & $0.47^{\mathrm{a}} \pm 0.15$ & $0.45 \pm 0.09$ & 0.033 & $0.32^{\mathrm{ns}}$ & - \\
\hline Co & $0.67^{\mathrm{a}} \pm 0.06$ & $0.47^{\mathrm{a}} \pm 0.05$ & $0.69^{\mathrm{a}} \pm 0.12$ & $0.61 \pm 0.08$ & 1.95 & $0.27^{\mathrm{ns}}$ & - \\
\hline \multicolumn{8}{|c|}{ Water (mg/l) } \\
\hline $\mathrm{Fe}$ & $0.44^{\mathrm{a}} \pm 0.02$ & $0.33^{\mathrm{b}} \pm 0.01$ & $0.47^{\mathrm{a}} \pm 0.01$ & $0.41 \pm 0.01$ & 11.25 & $0.07^{* * *}$ & $\leq 1.0$ \\
\hline Mn & $0.10^{\mathrm{b}} \pm 0.01$ & $0.10^{\mathrm{b}} \pm 0.01$ & $0.27^{\mathrm{a}} \pm 0.01$ & $0.16 \pm 0.01$ & 53.59 & $0.04^{* * *}$ & $\leq 0.5$ \\
\hline $\mathrm{Zn}$ & $0.09^{\mathrm{b}} \pm 0.00$ & $0.07^{\mathrm{a}} \pm 0.01$ & $0.03^{c} \pm 0.00$ & $0.06 \pm 0.00$ & 47.88 & $0.013^{* * *}$ & $\leq 1.0$ \\
\hline $\mathrm{Cu}$ & $0.04^{\mathrm{a}} \pm 0.00$ & $0.05^{\mathrm{a}} \pm 0.00$ & $0.06^{\mathrm{a}} \pm 0.00$ & $0.05 \pm 0.00$ & 1.43 & $0.015^{\mathrm{ns}}$ & $\leq 1.0$ \\
\hline $\mathrm{Pb}$ & $0.06^{\mathrm{b}} \pm 0.00$ & $0.06^{\mathrm{b}} \pm 0.00$ & $0.10^{\mathrm{a}} \pm 0.01$ & $0.07 \pm 0.00$ & 20.30 & $0.013^{* * *}$ & $\leq 0.05$ \\
\hline $\mathrm{Ni}$ & $0.03^{\mathrm{a}} \pm 0.00$ & $0.03^{\mathrm{a}} \pm 0.00$ & $0.03^{\mathrm{a}} \pm 0.00$ & $0.03 \pm 0.00$ & 3.2 & $0.009^{\mathrm{ns}}$ & - \\
\hline $\mathrm{Cd}$ & $0.03^{\mathrm{b}} \pm 0.00$ & $0.03^{\mathrm{b}} \pm 0.00$ & $0.04^{\mathrm{a}} \pm 0.01$ & $0.03 \pm 0.00$ & 4.19 & $0.014^{*}$ & $\leq 0.01$ \\
\hline Co & $0.03^{\mathrm{b}} \pm 0.00$ & $0.04^{\mathrm{b}} \pm 0.00$ & $0.07^{\mathrm{a}} \pm 0.00$ & $0.41 \pm 0.01$ & 19.21 & $0.011^{* * *}$ & - \\
\hline
\end{tabular}

*Egyptian standard regularities of article 60-law No. 48/1982 regarding minimum standards for the water quality of the Nile River. 


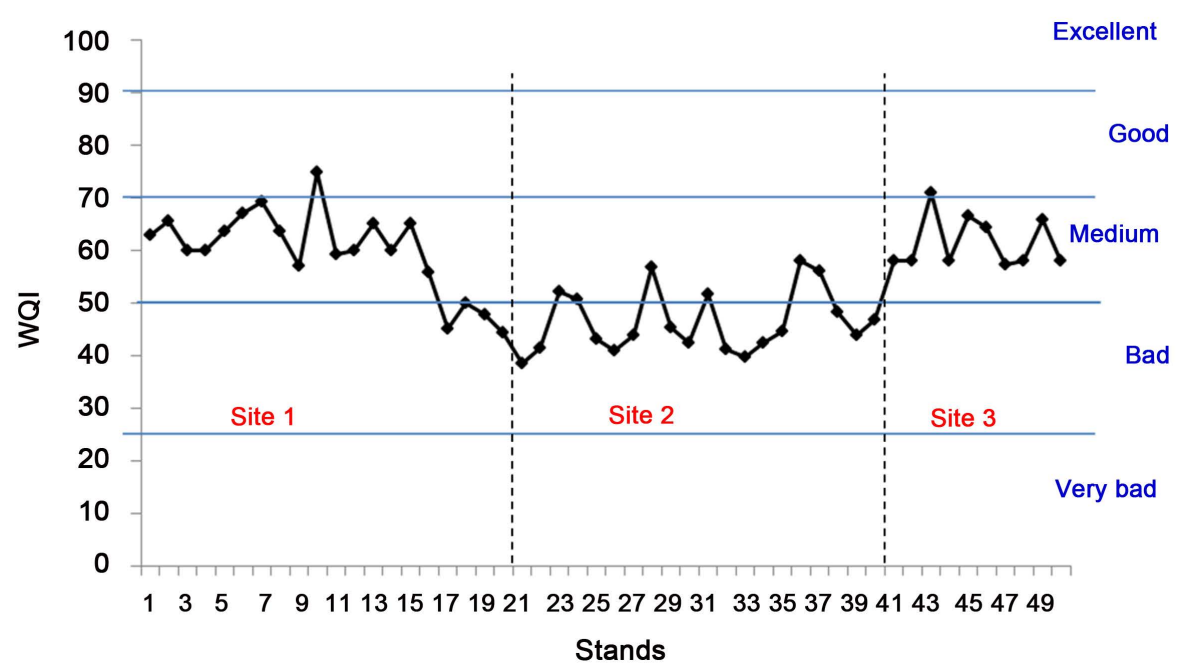

Figure 2. Variations in water quality index at the different sampling stands within the study area.

\section{Discussion}

\subsection{Sediment}

Soil is a precious natural resource, but its quality is deteriorated due to several anthropogenic activities [21]. The majority of grain size of the Rosetta sediments is fine sand especially nearby shoreline, this agrees with Abo Zed and Shereet [22]. Electrical conductivity ranged between 494.31 at site 2, while the highest mean value of EC in sediments samples was recorded in site 3 (Edfina-Rosetta) as a result of sea water intrusion. Overall, we can say that Edfina dam acts as artificial barrier which prevents natural equilibrium between Rosetta Branch and the Mediterranean Sea, this is agrees with El-Amier et al. [23] on environmental changes along Damietta Branch.

The highest mean value of organic carbon was recorded in site 3 , this may attributed to the transformation, the rate of precipitation and deposition of dead aquatic plants and different wastes in this site (the end of Rosetta Branch), this agrees with Venkatramanan et al. [24].

The highest mean value of total nitrogen in soil was recorded in site 1; this could be attributed to El-Rahawy drain, an agricultural drain which also receives sewage water [5]. While the highest mean value of TP in sediment was observed in site 2 as a result of different drainage water sources from Zawiet El-Bahr drain and Kafr El-Zayat City.

All the sediment samples after Edfina dam (site 3) are characterized by the domination of $\mathrm{HCO}_{3}^{-}$anion followed by $\mathrm{Cl}^{-}$and $\mathrm{SO}_{4}^{-}$. The cationic order of the sediment samples is: $\mathrm{Na}^{+}>\mathrm{Ca}^{2+}>\mathrm{Mg}^{2+}>\mathrm{K}^{+}$in all sites. The highest values were recorded in site 3 and lowest ones were at sites 1 and 2 . This could be attributed to the seawater intrusion, which agrees with Elkhatat et al. [25] and El-Amier et al. [23].

\subsection{Water}

Water pollution is one of the most principal environmental and public health problems in River Nile [23]. The highest mean value of EC in water was recorded in site 3, this could be attributed to drainage water in this area from land runoff which contains large amounts of cations and anions, this agrees with Ezzat et al. [26]. The values of $\mathrm{pH}$ increases also in site 3 may due to the flourishing and the photosynthesis process of aquatic plants also the water seems to be alkaline because of sea water intrusion according to Patra et al. [27], El Bouraie et al. [28] and Ibrahiem et al. [29]. The values of $\mathrm{pH}$ are within the Egyptian law [30].

The high concentrations of dissolved oxygen are very vital and important for aquatic organisms as it is required for the metabolism of aerobic organisms and organic matter decomposition [26]. The lowest mean value of dissolved oxygen was observed in site $1(10.40 \mathrm{mg} / \mathrm{l})$, this could be attributed to the drainage water from El-Rahawy drain which characterized by high load of organic wastes and the microbial activity that degraded the organic matter led to the oxygen consumption. While the highest mean value of DO (13.32 $\mathrm{mg} / \mathrm{l})$ was rec- 
orded in site 3 far away from drains. The values of DO are within the Egyptian law [30].

It's noticeable that BOD is very high especially in site 2, opposite to Kafr El-Zayat city, as there are many companies and drains and increasing of the organic load, while the lowest mean value was recorded in site 1, this agrees with Zyadah [8] and El-Alfy [31], the values of BOD is higher than value of Egyptian law [30].

Chemical oxygen demand defines as a measure of capacity of water to consume oxygen in decomposition of organic and inorganic matters [32]. The lowest mean value of COD (26.37 mg/l) was recorded in site 1 , while the highest mean value was observed in site 2 (69.87), this could be attributed to the industrial companies and agricultural activities in these areas, so huge amounts of sewage and domestic wastes concentrated in this site, also from the industrial effluents of El-Malyia Company discharging into the aquatic environment of the branch and this value is higher than (32) recorded by Abdo [33]. The values of COD are higher than the standard limits of Egyptian law [30].

The use of phosphate fertilizers tends to increase the phosphor content in water. Phosphate plays a role in plant and animal metabolism and thus occurs in their waste products. Domestic detergent and industrial sewage effluents represent important sources of phosphor in natural water. High concentrations of nutrients (i.e. T.P and T.N) can cause many problems to the river water quality such as; acidification, eutrophication and impairing the aquatic organisms to survive or grow [6] [34]. The lowest mean values of TP and TN were recorded in site 3, while the highest mean value of both were recorded in site 2 opposite to different drains that discharging huge amounts of sewage, domestic and agricultural wastes into the Rosetta Branch without any treatment, this leading to the increase in the concentration levels of nutrients. High values of TP and TN are related to agricultural wastes this agrees with the findings of Dougherty et al. [35] and Abdo [33].

Alkalinity is related to $\mathrm{pH}$, alkalinity of water may be caused due to $\mathrm{OH}, \mathrm{CO}_{3}, \mathrm{HCO}_{3}$ ions [36]. The lowest mean value of alkalinity $(105.44 \mathrm{mg} / \mathrm{l})$ was recorded at site 1 , while the highest mean value was recorded at site $2(164,99 \mathrm{mg} / \mathrm{l})$, this could be attributed to the decomposition of organic matter in this site.

Chlorides were higher in site 3, this due to sea water intrusion in site 3 [33], while sulphates is higher in site 2 may due to the effect of different drains distributed in Kafr El-Zayat City and different drains which increase sulphates in this area. Chloride concentrations higher than $200 \mathrm{mg} / \mathrm{L}$ are considered to be a risk for human health and may cause unpleasant taste of water [37]. However, Sulphates in high levels cause water hardening. Sulphates in these sites exceed the WHO permissible limit which is $200 \mathrm{mg} / \mathrm{l}$ [38].

Cations in water take the following sequence; $\mathrm{Na}^{+}>\mathrm{Ca}^{++}>\mathrm{K}^{+}>\mathrm{Mg}^{++} . \mathrm{Na}^{+}$is the most abundant between other cations; this could be attributed to the drainage water from different agricultural and cultivated lands [39]. Abdel-Halim [40] stated that $\mathrm{Ca}^{2+}$ concentrations in freshwater were more than $\mathrm{Mg}^{2+}$ and vice-versa in saline water whereas, $\mathrm{Ca}^{2+}$ is a preponderance over $\mathrm{Mg}^{2+}$ in sedimentary rocks.

From the calculations of WQI, it's noticeable that water quality index ranged from medium in site 1 (59.28) and site 3 (60) and bad in site 2 (44.28); this due to the drainage water from different drains in site 2 that effect on the water quality of Rosetta Branch.

\subsection{Heavy Metals}

Sediments are the main origin and source of heavy metals in the aquatic environment and play an important role in the transport and storage of potentially hazardous metals [41]. The concentrations of heavy metals in the sediments of different sites in Rosetta Branch take the following accumulation order: $\mathrm{Fe}>\mathrm{Mn}>\mathrm{Zn}>\mathrm{Cu}>\mathrm{Pb}>$ $\mathrm{Ni}>\mathrm{Co}>\mathrm{Cd}$. This indicated that Fe was the most accumulated element in sediment, whereas Cd was found to be the least concentration. This is agreeing with Yehia and Sebaee [42].

The highest concentrations of Fe and Zn were recorded in site 2 as a result of the drainage water from the industrial compound at Kafr El-Zayat City; this is agreeing with Masoud et al. [43] and El-Alfy [31]. Also, the increase of organic matter facilitates the deposition of Fe in sediment [44].

Manganese (Mn) is an essential trace nutrient in all forms of life. The highest mean value of $\mathrm{Mn}$ was recorded at site 1; this could be attributed to drainage water from El-Rahawy drain which is an agricultural drainage water source. Copper was high in site 2 that characterized by high clay percentage content, where there is significant correlation between copper and clay minerals as Fine-grained clay particles with more surface area contained more metals than coarse grained sand [45] [46]. Also this could be attributed to the industrial disposal in this site [47].

According to Waite [48], $\mathrm{Pb}$ normally exists in an un-dissolved form and in low concentration, except when 
water is polluted by exogenous inputs. The concentration of lead increases in site 2 than other sites may due to the agricultural drainage water or the deposition of dead plankton that increase its amount in the sediments, this is agree with Nafea [49] who found the same. Cd in the sediments of Rosetta Branch showed low high concentrations especially at site 1 as it is mostly correlated to agricultural activity especially the phosphatic fertilizers [31].

The highest mean value of $\mathrm{Ni}$ in the sediments was recorded at site 2; this could be attributed to sewage disposal from different drains. The highest mean value of cobalt was recorded at site 3 , may due to sea water intrusion or from urban runoff as concluded by [50].

Heavy metal pollution in water is generally associated with agricultural, industrial and municipal discharges into water resources [51]. The concentrations of heavy metals in water take the following sequence: $\mathrm{Fe}>\mathrm{Mn}>$ $\mathrm{Cu}>\mathrm{Pb}>\mathrm{Zn}>\mathrm{Cd}>\mathrm{Co}>\mathrm{Ni}$. The concentrations of Fe and $\mathrm{Cu}$ were found to be very high in water samples collected from site 3 , mainly due to the inflow of surface run off from agricultural wastes (agricultural and rocks) [39]. The relatively high $\mathrm{Zn}$ level is suggestive of the influence of refuse dump and domestic sewage sources. It could also be attributed to industrial effluents [52]. High concentrations of zinc were recorded in site 1, attributed to domestic wastes especially stands nearby El-Rahawy drain.

Cadmium is widely distributed in the aquatic environment. Cadmium and Lead are non-essential elements and higher concentrations can occur in aquatic organisms close to anthropogenic sources. These metals are toxic even at low concentrations and have no known function in biochemical processes [53]. The highest concentration of cadmium was recorded in site 1 nearby drainage wastewater especially industrial wastes. These results are in agreement with those obtained by Bahnasawy et al. [54] and Hamed et al. [47] who reported that the higher concentrations of $\mathrm{Cd}$ were due to the waste waters from different industrial activities without treatment directly to the aquatic systems. Manganese occurs in surface waters that are low in oxygen and often does so with Fe. So the highest concentration of Mn was observed in site 3, where the iron showed high values in the same site. While, there is no difference between the concentrations of $\mathrm{Ni}$ in water between these sites. The values of Co was high at site 3 , this could be attributed to urban runoff or sea water intrusion.

\section{Conclusion}

It's concluded that the drains along Rosetta Branch affect the water quality and may have an effect on the aquatic life. Huge amounts of pollutants are observed nearby El-Rahawy drain and close to the industrial compound in Kafr El-Zayat City. Trace metals with serious impacts are concentrated in wastewater especially as a result of industrial activities. Water quality index indicates that site two is more polluted and water quality is bad. The wastewater from point and non-point sources must be treated before being drained into the River water, which is a source of drinking and municipal uses in Egypt.

\section{Acknowledgements}

Sincere thanks to Dr. Muhammad El-Alfy, Research Assistant, National Institute of Oceanography and Fisheries (NIOF), Marine Pollution Department, for his help and support.

\section{References}

[1] Zahran, M.A. and Willis, A.J. (1992) The Vegetation of Egypt. Chapman and Hall, London. http://dx.doi.org/10.1007/978-94-015-8066-3

[2] Al Sherif, E.A. (2009) Ecological Studies on Hydrophytic Vegetation of Irrigation and Drainage Canal Systems in Beni Suef, Egypt. International Journal of Agriculture Biology, 11, 425-430.

[3] Engelman, R. and LeRoy, P. (1993) Sustainable Water; Population and the Future of Renewable Water Supplies. Population and Environment Program, Population Action International, Washington DC.

[4] Elewa, A.A., Shehata, M.B., Mohamed, L.F., Badr, M.H. and Abdel-Aziz, G.S. (2009) Water Quality Characteristics of the River Nile at Delta Barrage with Special Reference to Rosetta Branch. Global Journal of Environmental Research, 3, 1-6.

[5] Donia, N. (2005) Rosetta Branch Waste Load Allocation Model. 9th International Water Technology Conference, IWTC9, Sharm El-Sheikh, 17-20 March 2005, 277-288.

[6] Taha, A.A., El-Mahmoudi, A.S. and El-Haddad, I.M. (2004) Pollution Sources and Related Environmental Impacts in the New Communities' Southeast Nile Delta, Egypt. Emirates Journal for Engineering Research, 9, 35-49. 
[7] Chitmanat, C. and Traichaiyaporn, S. (2010) Spatial and Temporal Variations of Physical-Chemical Water Quality and Some Heavy Metals in Water, Sediments and Fish of the Mae Kuang River, Northern Thailand. International Journal of Agriculture and Biology, 12, 816-820.

[8] Zyadah, M. (1996) Occurrence of Heavy Metals in Some Fish Sediment and Water Samples from River Nile within Damietta Governorate. Proceedings of 6th International Conference Environment Protection Is a must, Alex, 21-23 May 1996, 929-942.

[9] Abdel-Dayem, S. (2011) Water Quality Management in Egypt. International Journal of Water Resources Development, 27, 181-202. http://dx.doi.org/10.1080/07900627.2010.531522

[10] Simoes, F., Moreira, A., Bisinoti, M., Gimenez, S. and Yabe, M. (2008) Water Quality Index as a Simple Indicator of Aquaculture Effects on Aquatic Bodies. Ecological Indicators, 8, 476-484. http://dx.doi.org/10.1016/j.ecolind.2007.05.002

[11] Fulazzaky, M.A., Seong, T. and Masirin, M. (2010) Assessment of Water Quality Status for the Selangor River in Malaysia. Water, Air and Soil Pollution, 205, 63-77. http://dx.doi.org/10.1007/s11270-009-0056-2

[12] Fulazzaky, M. (2009) Water Quality Evaluation System to Assess the Brantas River Water. Water Resources Management, 23, 3019-3033. http://dx.doi.org/10.1007/s11269-009-9421-6

[13] UNESCO (1977) Map of the World Distribution of Arid Regions. MAB Technical Notes, 7.

[14] Piper, C.S. (1947) Soil and Plant Analysis, Interscience Publishers, Inc., New York.

[15] Jackson, M.L. (1962) Soil Chemical Analysis. Constable and Co. Ltd., London.

[16] Pierce, W.C., Haenisch, E.L. and Sawyer, D.T. (1958) Quantitative Analysis. Wiley Toppen, Tokyo.

[17] APHA, American Public Health Association (1998) Standard Methods for the Examination of Water and Waste Water. 19th Edition, American Public Health Association, American Water Work Association, Water Pollution Control Federation, Washington DC.

[18] Allen, S.E., Grimshaw, H.M. and Rowland, A.P. (1986) Chemical Analysis. In: Moore, P.D. and Chapman, S.B., Eds., Methods of Plant Ecology, Blackwell, Oxford, 285-344.

[19] Allen, S.E., Grimshaw, H.M., Parkinson, J.A., Quarmby, C. and Roberts, J.D. (1974) Chemical Analysis of Ecological Materials. Blackwell Scientific Publications, Osney, Oxford and London.

[20] Baruah, T.C. and Barthakur, H.P. (1997) A Text Book of Soil Analysis. Vikas Publishing House Pvt Ltd., New Delhi.

[21] Ramakrishnaiah, H. and Somashekar, R.K. (2002) Heavy Metal Contamination in Roadside Soil and Their Mobility in Relations to $\mathrm{pH}$ and Organic Carbon. Soil and Sediment Contamination, 11, 643-654. http://dx.doi.org/10.1080/20025891107014

[22] Abo Zed, A.I. and Shereet, S.M. (2005) Dynamics of Near Shore Sediments and Coastal Changes astride Rosetta Branch, Egypt. Emirates Journal for Engineering Research, 10, 51-61.

[23] El-Amier, Y.A., Zahran, M.A. and Al-Mamoori, S.O. (2015) Environmental Changes along Damietta Branch of the River Nile, Egypt. Journal of Environmental Sciences, Mansoura University, 44, 235-255.

[24] Venkatramanan, S., Ramkumar, T. and Anitha Mary, I. (2010) Textural Characteristics and Organic Matter Distribution Patterns in Tirumalairajanar River Estuary, Tamilnadu, East Coast of India. International Journal of Geomatics and Geosciences, 1, 552-562.

[25] Elkhatat, A.M., Sadek, M.A., Salem, W.M. and Elshahat, M.F. (2013) Impacts of Dams on the Chemical and Isotopic Properties of Damietta Branch of River Nile. Journal of Environmentally Friendly Processes, 1, 1-13. http://dx.doi.org/10.14266/jefp11-2

[26] Ezzat, S.M., Mahdy, H.M., Abo-State, M.A., Abd El Shakour, E.H. and El-Bahnasawy, M.A. (2012) Water Quality Assessment of River Nile at Rosetta Branch: Impact of Drains Discharge. Middle-East Journal of Scientific Research, 12, 413-423.

[27] Patra, A.P., Patra, J.K., Mahapatra, N.K., Das, S. and Swain, G.C. (2010) Seasonal Variation in Physicochemical Parameters of Chilika Lake after Opening of New Mouth near Gabakunda, Orissa, India. World Journal of Fish and Marine Sciences, 2, 109-117.

[28] El Bouraie, M.M., Motawea, E.A., Mohamed, G.G. and Suoseura, M.Y. (2011) Water Quality of Rosetta Branch in Nile Delta, Egypt. Finnish Peatland Society, 62, 31-37.

[29] Ibrahiem, M.S., El-Sonbati, M.A. and El-Alfy, M.A. (2012) Detection of Industrial Pollution at the Northeastern Part of Manzala Lagoon, Egypt. Journal of Environmental Sciences, 41, 211-235.

[30] Egyptian Law (48/1982) The Implementer Regulations for Law 48/1982 regarding the Protection of the River Nile and Water Ways from Pollution. Map. Periodical Bulletin, 3-4 December, 12-35. 
[31] El-Alfy, M.A. (2011) An Integrated Approach for Monitoring the Impact of Industrial Activities on the Northeastern Part of Manzala Lagoon, Egypt. Master’s Thesis, Environmental Sciences Department, Damietta Faculty of Science, Mansoura University, Mansoura.

[32] El-Gohary, S.E., Zaki, H.R. and Elnaggar, M.F. (2011) Physicochemical and Eutrophication Parameters of Coastal Water and Geochemical Characteristics of Bottom Sediments East of Rosetta Area, Meditteranean Sea, Egypt. World Applied Science Journal, 14, 23-36.

[33] Abdo, M.H. (2013) Physico-Chemical Studies on the Pollutants Effect in the Aquatic Environment of Rosetta Branch River Nile, Egypt. Life Science Journal, 10, 493-501.

[34] Camargo, J.A. and Alonso, A. (2006) Ecological and Toxicological Effects of Inorganic Nitrogen Pollution in Aquatic Ecosystems: A Global Assessment. Environment International, 32, 831-849. http://dx.doi.org/10.1016/j.envint.2006.05.002

[35] Doughterty, W.J., Fleming, N.K., Coxand, J.W. and Chitleborough, D.T. (2004) Phosphorus Transfer in Surface Runoff from Intensive Pasture Systems at Various Scales: A Review. Journal of Environmental Quality, 33, 1973-1973. http://dx.doi.org/10.2134/jeq2004.1973

[36] Tekade, P.V., Mohabansi, N.P. and Patil, V.B. (2011) Study of Physico-Chemical Properties of Effluents from Soap Industry in Wardha. Rasayan Journal of Chemistry, 4, 461-465.

[37] Versari, A., Parpinello, G.P. and Galassi, S. (2002) Chemometric Survey of Italian Bottled Mineral Waters by Means of Their Labelled Physico-Chemical and Chemical Composition. Journal of Food Composition and Analysis, 15, 251264. http://dx.doi.org/10.1006/jfca.2002.1058

[38] WHO (1993) Guidelines for Technologies for Water Supply Systems in Small Communities. World Health Organization, Geneva.

[39] Arain, M.B., Kazi, T.G., Jamali, M.K., Afridi, H.I., Baig, J.A., Jalbani, N. and Shah, A. (2008) Evaluation of Physico-Chemical Parameters of Manchar Lake Water and Their Comparison with Other Global Published Values. Pakistan Journal of Analytical \& Environmental Chemistry, 9, 101-109.

[40] Abdel-Halim, A.M. (1993) Studies on the Physicochemical Changes of the River Nile at the Region from Isna to El-Kanater El-Khyria, Egypt. Master's Thesis, Faculty of Science, Alexandria University, Alexandria.

[41] Liu, E., Shen, J., Yang, L., Zhang, E., Meng, X. and Wang, J. (2009) Assessment of Heavy Metal Contamination in the Sediments of Nansihu Lake Catchment, China. Environmental Monitoring and Assessment, 161, 217-227. http://dx.doi.org/10.1007/s10661-008-0739-y

[42] Yehia, H.M. and Sebaee, E.S. (2012) Bioaccumulation of Heavy Metals in Water, Sediment and Fish (Oreochromis niloticus and Clarias anguillaris), in Rosetta branch of the River Nile, Egypt. African Journal of Biotechnology, 11, 14204-14216. http://dx.doi.org/10.5897/AJB11.3745

[43] Masoud, M.S., Fahmy, M.A., Ali, A.E. and Mohamed, E.A. (2011) Heavy Metal Speciation and Their Accumulation in Sediments of Lake Burullus, Egypt. African Journal of Environmental Science and Technology, 5, 280-298.

[44] Abdo, M.H. (2005) Physico-Chemical Characteristics of Abu Za'baal Ponds. Egyptian Journal of Aquatic Research, 31, 1-15.

[45] Saeed, S.M. and Shaker, I.M. (2008) Assessment of Heavy Metals Pollution in Water and Sediments and Their Effect on Oreochromis niloticus in the Northern Delta Lakes, Egypt. Proceedings of the 8th International Symposium on Tilapia in Aquaculture, Cairo, 12-14 October 2008, 475-490.

[46] Ugwu, A.I., Wakawa R.J., Laah, E. and Olotu, A. (2012) Spatial Distribution of Heavy Metals in River Usuma Sediments and Study of Factors Impacting the Concentration. International Journal of Research and Reviews in Applied Sciences, 12, 294-303.

[47] Hamed, Y.A., Abdelmoneim, T.S., ElKiki, M.H., Hassan, M.A. and Berndtsson, R. (2013) Assessment of Heavy Metals Pollution and Microbial Contamination in Water, Sediments and Fish of Lake Manzala, Egypt. Life Science Journal, 10, 86-99.

[48] Waite, T.D. (1984) Principles of Water Quality. Academic Press, London.

[49] Nafea, E. (2005) A Study on the Ecology and Sustainable Development of the Northern Delta Lakes, Egypt. PhD Thesis, Faculty of Science, Mansoura University, Mansoura, 33.

[50] Nagpal, N.K. (2004) Technical Report—Water Quality Guidelines for Cobalt. Water Quality—Standards—British Columbia. Ministry of Water, Land and Air Protection, 6.

[51] Zaghloul, H.K. (2001) Usage of Zinc and Calcium in Inhibiting the Toxic Effect of Copper on the African Carfish; Clarias gariepinus. Egyptian German Society of Zoology, 35, 99-120.

[52] Lawson, E.O. (2011) Physico-Chemical Parameters and Heavy Metal Contents of Water from the Mangrove Swamps 
of Lagos Lagoon, Lagos, Nigeria. Advances in Biological Research, 5, 8-21.

[53] El-Naggar, S.M. and Tayel, S. (2009) Bioaccumulation of Some Heavy Metals and Histopathological Alterations in Liver of Oreochromis niloticus in Relation to Water Quality at Different Localities along the River Nile, Egypt. World Journal of Fish and Marine Sciences, 1, 105-114.

[54] Bahnasawy, M.H., Khidr, A.A. and Dheina, N.A. (2011) Assessment of Heavy Metal Concentrations in Water, Plankton, and Fish of Lake Manzala, Egypt. Turk Journal of Zoology, 35, 271-280. 